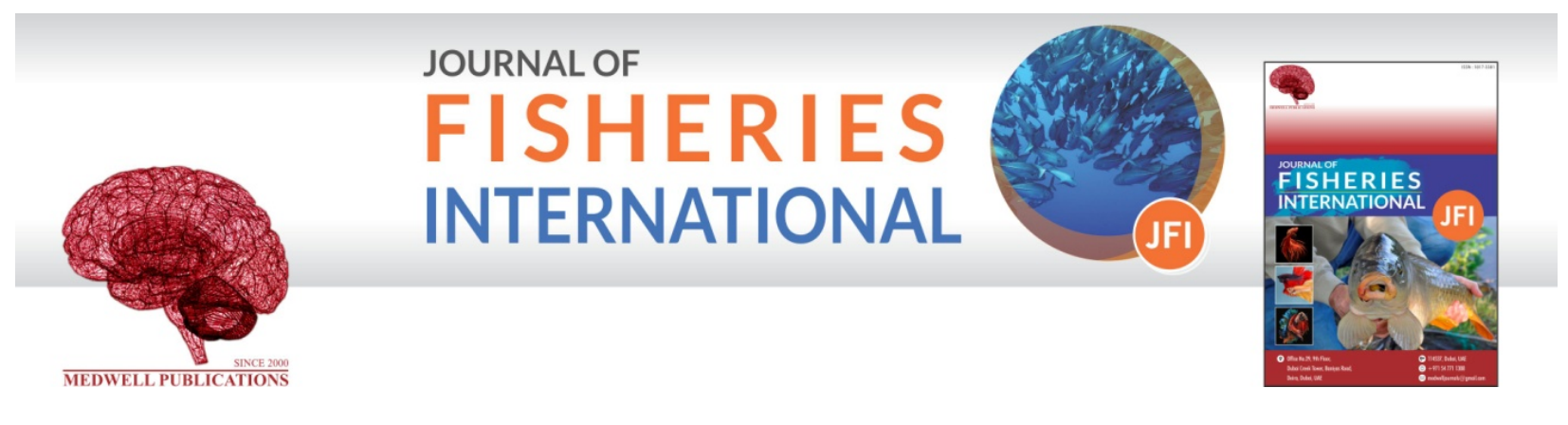

\title{
Metabolite Changes in the Blood Plasma of Juvenile and Adult African Mudfish (Clarias gariepinus) on Exposure to Detergent (Linear Alkylbenzene Sulphonate)
}

\author{
${ }^{1}$ A.D.I. George and ${ }^{2}$ B. Uedeme-Naa \\ ${ }^{1}$ Department of Fisheries and Aquatic Environment, Faculty of Agriculture, Rivers State University, \\ Port Harcourt, Nigeria \\ ${ }^{2}$ Department of Fisheries, University of Port Harcourt, Rivers State, Nigeria
}

Key words: Linear alkylbenzene sulfonate, total protein, juveniles, albumin, plasma metabolites, creatinine, urea

\section{Corresponding Author:}

B. Uedeme-Naa

Department of Fisheries, University of Port Harcourt, Rivers State, Nigeria

Page No.: 1-6

Volume: 15, Issue 1, 2020

ISSN: $1817-3381$

Journal of Fisheries International

Copy Right: Medwell Publications
Abstract: The aim of this research was to evaluate the effect of detergent (linear alkylbenzene sulphonate) on selected blood plasma metabolites of African mudfish (Clarias gariepinus) juveniles and adults. The effect was assessed by comparing blood plasma metabolites profile in the two live stages of a control group $\left(0.00 \mathrm{mg} \mathrm{L}^{-1}\right)$ and that exposed to varied concentration of detergent $\left(10.00,20.00,30.00,40.00\right.$ and $\left.50.00 \mathrm{mg} \mathrm{L}^{-1}\right)$. Compared with control group, albumin was 10.92, 8.48, 9.10\% higher than control at 10.00, 20.00 and $30.00 \mathrm{mg} \mathrm{L}^{-1}$ and $12.08,14.97 \%$ lower at 40.00 and $50.00 \mathrm{mg} \mathrm{L}^{-1}$ for juveniles while for adult fish it was significantly $(\mathrm{p}>0.05)$ higher than control at all the concentration levels. Total protein was $11.70,15.20,15.79,22.22$ and $28.07 \%$ higher than control at all levels and significantly not found in the adult. Creatinine was respectively 45.29, 125.96, 55.25 and $50.36 \%$ higher than control at 10.00, 20.00, 30.00 and 50.00 and $2.75 \%$ less than control at $40.00 \mathrm{mg} \mathrm{L}^{-1}$ while in adult fish it was observed that at $10.00-50.00 \mathrm{mg} \mathrm{L}^{-1}$, creatinine was respectively 72.73, 157.27, 239.09 and $280.00 \%$ higher than control. Interestingly, total bilirubin in juvenile fish was $69.50,76.12,86.91,76.12$ and $92.09 \%$ less than control while in adult fish, it was 15.58 , $32.92,63.03,114.95$ and $136.24 \%$ higher than control at 10.00-50.00 $\mathrm{mg} \mathrm{L}^{-1}$. The exposed group for juvenile and adult fish showed a significantly higher $(\mathrm{p}<0.05)$ concentration of urea when compared with that of the control group.

\section{INTRODUCTION}

According to Hinton and Lauren ${ }^{[1]}$ it is important to realize that physiological and biochemical alterations, if severe enough or protracted will lead to structural alterations. Changes may be seen in the distribution of molecules on the cell surface, the organelle number, volume, shape or distribution, cell volume, morphology, cell distribution or number and organ volume and relative weight $^{[2]}$. Therefore, biochemical characteristics of specific organs express condition and represent time integrated endogenous and exogenous impacts on the organism stemming from alterations at lower levels of biological organization ${ }^{[3]}$. In addition, biochemical 
changes occur earlier than reproductive changes and are more sensitive than growth or reproductive parameters. As an integrative parameter, histological changes provide better evaluation of an organism's health than a single biochemical parameter ${ }^{[4]}$. For field assessments, biochemical analysis is often the easiest method of assessing both short and long-term toxic effects. If level of a stressor is high enough, lethal changes may occur within an entire organ or specific regions within the organ. If tissues are properly fixed immediately after an animal dies, stressor-dependent pre-mortem cell death and necrosis can be differentiated from post-mortem changes ${ }^{[5]}$.

In general, the presence of toxicants in aquatic media exerts its effect at cellular or molecular level which results in significant changes in biochemical parameters. Due to metal complex formation, normal functioning of cell is disturbed and that in turn may result in variation on physiological and biochemical mechanisms of animals ${ }^{[6]}$. Bielinska $^{[7]}$ also reported that sodium hypochlorite; a common bleaching agent of detergents enhances lipid peroxidation in blood lipoproteins and phospholipid liposomes. A comparative study conducted by Panasenko et al..$^{[8]}$ on the toxicity of some commercial detergents on Nile tilapia, Oreochromis niloticus revealed their adversity to survival of the species. Study on the role of linear alkyl benzene sulfonate using the common detergent "Henko" on Puntius ticto revealed the histopatological lesions on gill archs, rakers and gill filaments ${ }^{[9]}$. Study on toxicological impact of house hold detergent "Surf" on digestive tissue on fresh-water fish Clarius batrachus marked the large scale destruction of the tissues of gastro-intestinal mucosa and liver. Surfactants were found to increase the absorption of xenobiotics in rat colon augmenting the adverse effects. Emulgen 913 (polyoxyethylene glycol, nonyl phenol ether) decreased the liver weight and cytochrome P450, cytochrome b5 and microsomal heme content in rats whereas heme oxygenase was greatly enhanced. Emulgen 813 also significantly reduced the concentration of metal binding proteins in the hepatopancreas and decreased the heme oxygenase activity in the kidney of red carp ${ }^{[10]}$. Toxicity of Swascol IP (SLS) to Channa punctatus and Cirrhina mrigala was studied by Benli.

\section{MATERIALS AND METHODS}

One hundred and fifty juveniles with mean weight, $246.30 \pm 14.12 \mathrm{~g} \mathrm{SD}$; mean length $16.15 \pm 1.40 \mathrm{~cm} \mathrm{SD}$ ) and thirty adults with mean weight, $850.00 \pm 10.22 \mathrm{~g} \mathrm{SD}$; mean length $29.20 \pm 7.12 \mathrm{~cm} \mathrm{SD}$ ) of $C$. gariepinus procured from Abduls Fish Farm Rukpakulusi, Port Harcourt, Rivers state. Nigeria were used for this toxicity assay while test solution (commercial detergent containing linear alkylbenzene sulphonate) used was purchased from great grace super market in Port Harcourt. The utilization of these two life stages was due to general believe and assumption that juveniles are more sensitive to toxicity test than the adults. The test organisms were acclimated in thirty rectangular plastic aquaria containing $20 \mathrm{~L}$ of water each for 7 days. The top of the aquaria were covered with net to prevent fish from escape. Fish were fed with commercial pellet once daily with a $42 \%$ crude protein diet at $2 \%$ body weight for juvenile fish and $1 \%$ for adult fish. The remnants containing unconsumed feed and fecal were removed from the stock tanks and water replenished every $24 \mathrm{~h}$ as recommended by Reish and Oshida, Oyelese and Fasoranti and Odiette.

Chronic toxicity test: A static renewable bioassay procedure (ASTM 1990) was adopted in which test media was regularly renewed at intervals of $24 \mathrm{~h}$ at the same concentrations. Preliminary investigations were carried out to determine the definitive concentration as described by Santanu. Based on this, five different concentrations (treatments) of the detergent were used excluding the control stock all in replicates of five for each live stage in the order of 10.00, 20.00, 30.00, 40.00 and $50.00 \mathrm{mg} \mathrm{L}^{-1}$. Five replicates were also put in place for control $\left(0.00 \mathrm{mg} \mathrm{L}^{-1}\right)$ for a period of 30 days. In all the treatments including control, 150 and 30 juveniles and adults were respectively fully acclimated test organisms were held as described by Rahman. This was to maintain constant concentration of the test media to which test organisms were exposed and to prevent accumulation of toxic metabolites. The chronic test was allowed to stand for 30 days. After the experiment, fish were killed with a blow on the head after blood collection and dissected in order to collect target organs such as gill, liver, kidney, muscle and spleen tissues $(0.5 \mathrm{~g}$ each) with the aid of penknife as described by Luna etc. Samples were macerated with pestle and mortar. To prepare samples for metabolite, $5 \mathrm{~mL}$ of perchloric acid was used for each organ. After the addition of these diluents, the samples were centrifuged at the rate of 300 rounds per minutes for $10 \mathrm{~min}$. The supernatants were then removed and stored in plain bottles at $-4^{\circ} \mathrm{C}$ for analysis using Canil method.

Ammonia, alkalinity, temperature, $\mathrm{pH}$, conductivity, turbidity and dissolved oxygen were adequately monitored. Ammonia-Nitrogen (NH3-N) was determined using phenate method, temperature was determined with a mercury-in glass thermometer, $\mathrm{pH}$ was measured with $291 \mathrm{Mk} 2 \mathrm{pH}$ meter, conductivity and turbidity were measured with Horiba water checker probe. Dissolved oxygen was measured using Winkler's method.

\section{RESULTS AND DISCUSSION}

The physicho-chemical analysis of the detergent solution for the two life stages was computed in Table 1, 2 and Fig. 1 (compared life stages). The result for the analysis, however, implicated the impact of detergent 


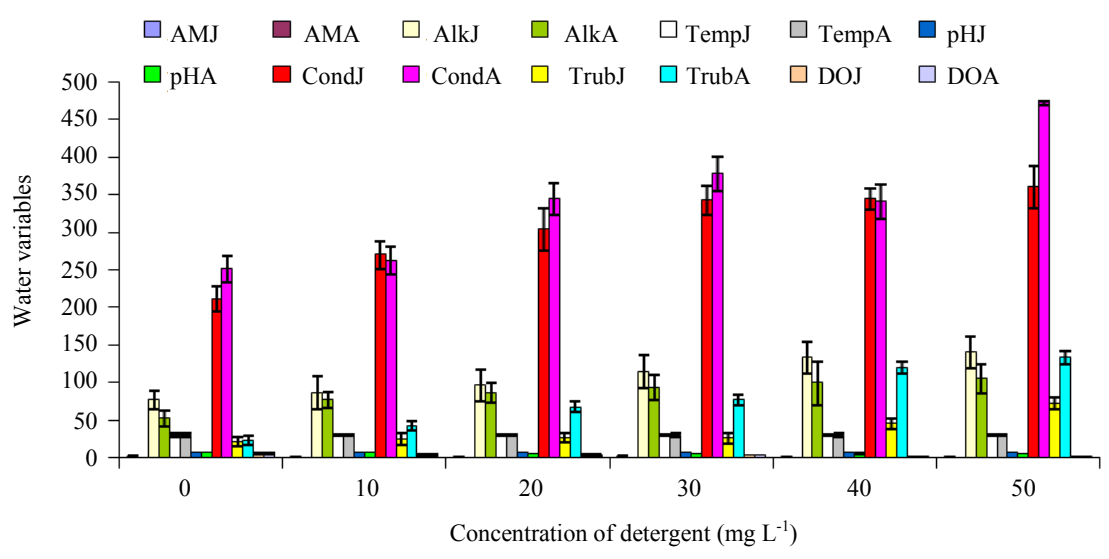

Fig. 1: Water quality variables (Mean $\pm \mathrm{SD}$ ) in the experimental aquaria for juvenile and adult $C$. gariepinus. $\mathrm{AMJ}=$ Ammonia for Juvenile, AMA = Ammonia for Adult, AlkJ = Alkalinity for Juvenile, AlkA = Alkalinity for Adult, TempJ $=$ Temperature for Juvenile, TempA $=$ Temperature for Adult, $\mathrm{pHJ}=-\log$. of Hydrogen ion concentration for Juvenile, $\mathrm{pHA}=\mathrm{-} \log$. of Hydrogen ion concentration for Adult, CondJ = Conductivity for Juvenile, CondA $=$ Conductivity for Adult, TurJ $=$ Turbidity for Juvenile, TurA $=$ Turbidity for Adult, DOJ $=$ Dissolved Oxygen for Juvenile, DOA = Dissolved Oxygen for Adult

Table 1: Water quality variables (Mean $\pm \mathrm{SD})$ in the experimental tanks for juveniles during the exposure period

\begin{tabular}{|c|c|c|c|c|c|c|}
\hline \multirow[b]{2}{*}{ Variables } & \multicolumn{6}{|c|}{ Concentrations $\left(\mathrm{mg} \mathrm{L}^{-1}\right)$} \\
\hline & 0.00 & 10.00 & 20.00 & 30.00 & 40.00 & 50.00 \\
\hline$\overline{\text { Ammonia }\left(\mathrm{mg} \mathrm{L}^{-1}\right)}$ & $1.76 \pm 0.28^{\mathrm{a}}$ & $1.59 \pm 0.37^{\mathrm{a}}$ & $1.44 \pm 0.43^{\mathrm{a}}$ & $1.54 \pm 0.62^{\mathrm{a}}$ & $1.49 \pm 0.20^{\mathrm{a}}$ & $1.44 \pm 0.40^{\mathrm{a}}$ \\
\hline Alkalinity $\left(\mathrm{mg} \mathrm{L}^{-1}\right)$ & $77.00 \pm 12.76^{\mathrm{a}}$ & $87.00 \pm 21.64^{\mathrm{a}}$ & $96.00 \pm 21.14^{\mathrm{ab}}$ & $115.00 \pm 21.66^{\mathrm{b}}$ & $133.00 \pm 21.12^{\mathrm{b}}$ & $141.12 \pm 21.11^{\mathrm{b}}$ \\
\hline Temperature $\left({ }^{\circ} \mathrm{C}\right)$ & $30.42 \pm 2.33^{\mathrm{a}}$ & $30.27 \pm 0.48^{\mathrm{a}}$ & $30.45 \pm 0.63^{\mathrm{a}}$ & $30.55 \pm 0.59^{\mathrm{a}}$ & $30.70 \pm 0.73^{\mathrm{a}}$ & $30.71 \pm 0.84^{\mathrm{a}}$ \\
\hline $\mathrm{pH}$ & $6.39 \pm 0.57^{\mathrm{a}}$ & $6.45 \pm 0.65^{\mathrm{a}}$ & $6.68 \pm 0.30^{\mathrm{a}}$ & $6.60 \pm 0.14^{\mathrm{a}}$ & $6.60 \pm 0.16^{\mathrm{a}}$ & $6.40 \pm 0.21^{\mathrm{a}}$ \\
\hline Conductivity $\left(\mathrm{S} \mathrm{m}^{-1}\right)$ & $211.50 \pm 16.71^{\mathrm{a}}$ & $270.25 \pm 18.61^{\mathrm{ab}}$ & $303.75 \pm 28.11^{\mathrm{b}}$ & $343.25 \pm 19.621^{\mathrm{b}}$ & $345.25 \pm 14.11^{\mathrm{b}}$ & $360.11 \pm 28.11^{\circ}$ \\
\hline Turbidity (mg L $\left.{ }^{-1}\right)$ & $21.50 \pm 6.23^{\mathrm{a}}$ & $25.00 \pm 7.16^{\mathrm{b}}$ & $27.00 \pm 6.21^{\mathrm{b}}$ & $26.11 \pm 7.11^{\mathrm{b}}$ & $45.00 \pm 7.11^{\mathrm{c}}$ & $73.00 \pm 8.11^{\mathrm{d}}$ \\
\hline $\mathrm{DO}\left(\mathrm{mg} \mathrm{L}^{-1}\right)$ & $5.59 \pm 0.98^{\mathrm{c}}$ & $3.81 \pm 0.68^{\mathrm{ab}}$ & $3.20 \pm 0.72^{\mathrm{ab}}$ & $2.95 \pm 0.64^{\mathrm{b}}$ & $2.55 \pm 0.33^{\mathrm{b}}$ & $2.33 \pm 0.13^{\mathrm{b}}$ \\
\hline
\end{tabular}

Table 2: Water quality variables $(\mathrm{Mean} \pm \mathrm{SD})$ in the experimental tanks for adult fish during exposure period

\begin{tabular}{|c|c|c|c|c|c|c|}
\hline \multirow[b]{2}{*}{ Variables } & \multicolumn{6}{|c|}{ Concentrations $\left(\mathrm{mg} \mathrm{L}^{-1}\right)$} \\
\hline & 0.00 & 10.00 & 20.00 & 30.00 & 40.00 & 50.00 \\
\hline Ammonia $\left(\mathrm{mg} \mathrm{L}^{-1}\right)$ & $0.83 \pm 0.15^{\mathrm{a}}$ & $1.17 \pm 0.17^{\mathrm{b}}$ & $1.49 \pm 0.23^{\mathrm{c}}$ & $1.20 \pm 0.0 .8^{\mathrm{b}}$ & $1.28 \pm 0.19^{\mathrm{b}}$ & $1.37 \pm 0.21^{\mathrm{c}}$ \\
\hline Alkalinity $\left(\mathrm{mg} \mathrm{L}^{-1}\right)$ & $52.00 \pm 10.00^{\mathrm{a}}$ & $77.00 \pm 11.20^{\mathrm{b}}$ & $87.00 \pm 13.02^{\mathrm{b}}$ & $93.75 \pm 16.00^{\mathrm{b}}$ & $99.50 \pm 28.82^{\mathrm{ab}}$ & $105.00 \pm 20.03^{\mathrm{b}}$ \\
\hline Temperature $\left({ }^{\circ} \mathrm{C}\right)$ & $30.43 \pm 2.31^{\mathrm{a}}$ & $30.28 \pm 1.31^{\mathrm{a}}$ & $30.45 \pm 0.36^{\mathrm{a}}$ & $30.55 \pm 2.31^{\mathrm{a}}$ & $30.70 \pm 2.33^{\mathrm{a}}$ & $30.70 \pm 0.91^{\mathrm{a}}$ \\
\hline $\mathrm{pH}$ & $6.65 \pm 0.57^{\mathrm{a}}$ & $6.21 \pm 0.22^{\mathrm{a}}$ & $6.13 \pm 0.20^{\mathrm{a}}$ & $5.84 \pm 0.23^{\mathrm{ab}}$ & $5.56 \pm 0.21^{\mathrm{ab}}$ & $4.89 \pm 0.24^{b}$ \\
\hline Conductivity $\left(\mathrm{S} \mathrm{m}^{-1}\right)$ & $251.25 \pm 17.17^{\mathrm{a}}$ & $262.50 \pm 18.32^{\mathrm{a}}$ & $345.50 \pm 21.22^{\mathrm{b}}$ & $378.00 \pm 23.01^{\mathrm{b}}$ & $340.75 \pm 23.23^{b}$ & $472.75 \pm 25.00^{\circ}$ \\
\hline Turbidity (mg L $\left.{ }^{-1}\right)$ & $23.00 \pm 6.11^{\mathrm{a}}$ & $42.75 \pm 6.20^{\mathrm{a}}$ & $67.50 \pm 7.01^{\mathrm{ab}}$ & $77.25 \pm 7.04^{\mathrm{ab}}$ & $120.00 \pm 8.02^{\mathrm{c}}$ & $133.00 \pm 9.23^{\mathrm{d}}$ \\
\hline $\mathrm{DO}\left(\mathrm{mg} \mathrm{L}^{-1}\right)$ & $5.98 \pm 0.99^{\mathrm{b}}$ & $4.32 \pm 0.54^{\mathrm{b}}$ & $3.58 \pm 0.34^{\mathrm{ab}}$ & $3.21 \pm 0.30^{\mathrm{ab}}$ & $2.56 \pm 0.28^{\mathrm{a}}$ & $2.34 \pm 0.25^{\mathrm{a}}$ \\
\hline
\end{tabular}

Means within the same row with different superscripts ${ }^{(\mathrm{a}, \mathrm{b}, \mathrm{ab}, \mathrm{c}, \mathrm{d})}$ differ significantly $(\mathrm{p}<0.05)$

solution when compared with control in that alkalinity, conductivity, turbidity and dissolved oxygen in the aquaria with both life stages were significantly raised $(p<0.05)$ with increase in detergent concentration while ammonia in juvenile aquaria decreased and that of adult increased significantly. Temperature was not significantly influenced but it noticed that the $\mathrm{pH}$ in juvenile aquaria significantly increased while that of adult dropped with increase in concentration (Table 1, 2 and Fig. 1).

Albumin in adult fish was higher than that of juvenile fish by $12.89 \%$ at $10.00 \mathrm{mg} \mathrm{L}^{-1} ; 39.15 \%$ at $20.00 \mathrm{mg} \mathrm{L}^{-1}$ and $71.85 \%$ at $30.00 \mathrm{mg} \mathrm{L}^{-1}$. At 40.00 and $50.00 \mathrm{mg} \mathrm{L}^{-1}$ albumin in juvenile fish was respectively 12.08 and $14.29 \%$ less than control while that of adult fish was 85.71 and $109.52 \%$ higher than control (Table 3 and 4). Total protein was not detected in adult fish (Table 4) whereas that of juvenile fish increased with increase in detergent concentration (Table 3). At 10.00, 30.00, 40.00 and $50.00 \mathrm{mg} \mathrm{L}^{-1}$, creatinine in adult fish was respectively higher than that of juvenile by $27.44,102.02$, 239.09 and $224.64 \%$ and lower than that of juvenile by $53.26 \%$ at $20.00 \mathrm{mg} \mathrm{L}^{-1}$. In juvenile fish, detergent resulted in the decrease of total protein by $69.50 \%$ at $10.00 \mathrm{mg} \mathrm{L}^{-1}, 76.12 \%$ at $20.00 \mathrm{mg} \mathrm{L}^{-1}, 86.91 \%$ at 
J. Fish. Int., 15 (1): 1-6, 2020

Table 3: Selected metabolites in the plasma of C. gariepinus juveniles exposed to detergent for 30 days (Mean $\pm \mathrm{SD}$ )

\begin{tabular}{|c|c|c|c|c|c|c|c|c|c|c|}
\hline $\begin{array}{l}\text { Conc. } \\
\left(\mathrm{mg} \mathrm{L}^{-1}\right)\end{array}$ & $\begin{array}{l}\text { Albumin } \\
\left(\mathrm{mg} \mathrm{L}^{-1}\right)\end{array}$ & $\begin{array}{l}\text { Control } \\
(\%)\end{array}$ & $\begin{array}{l}\text { Total protein } \\
\left(\mathrm{mg} \mathrm{L}^{-1}\right)\end{array}$ & $\begin{array}{l}\text { Control } \\
(\%)\end{array}$ & $\begin{array}{l}\text { Creatinin } \\
\left(\mathrm{mg} \mathrm{L}^{-1}\right)\end{array}$ & $\begin{array}{l}\text { Control } \\
(\%)\end{array}$ & $\begin{array}{l}\text { Total bilirubin } \\
\left(\mathrm{mg} \mathrm{L}^{-1}\right)\end{array}$ & $\begin{array}{l}\text { Control } \\
(\%)\end{array}$ & $\begin{array}{l}\text { Urea } \\
\left(\mathrm{mg} \mathrm{L}^{-1}\right)\end{array}$ & $\begin{array}{l}\text { Control } \\
(\%)\end{array}$ \\
\hline 0.00 & $19.13 \pm 7.3^{\mathrm{a}}$ & 100 & $42.75 \pm 8.92^{\mathrm{a}}$ & 100 & $5.52 \pm 1.21^{\mathrm{a}}$ & 100 & $34.75 \pm 16.82^{\mathrm{c}}$ & 100 & $9.10 \pm 7.10^{\mathrm{a}}$ & 100 \\
\hline 10.00 & $21.20 \pm 5.1^{\mathrm{b}}$ & +10.92 & $47.75 \pm 7.04^{\mathrm{a}}$ & +11.70 & $8.02 \pm 2.08^{b}$ & +45.29 & $10.60 \pm 3.16^{\mathrm{b}}$ & -69.50 & $12.40 \pm 2.09^{\mathrm{ab}}$ & +36.67 \\
\hline 20.00 & $20.75 \pm 11.4^{\mathrm{b}}$ & +8.47 & $49.25 \pm 6.45^{\mathrm{a}}$ & +15.20 & $12.47 \pm 7.76^{\mathrm{ab}}$ & +125.96 & $8.30 \pm 1.04^{\mathrm{b}}$ & -76.12 & $18.07 \pm 6.79^{\mathrm{b}}$ & +98.57 \\
\hline 30.00 & $20.87 \pm 6.2^{b}$ & +9.10 & $49.50 \pm 4.36^{\mathrm{a}}$ & +15.79 & $8.57 \pm 5.03^{\mathrm{b}}$ & +55.25 & $4.55 \pm 1.10^{\mathrm{a}}$ & -86.91 & $18.50 \pm 5.95^{\mathrm{b}}$ & +103.30 \\
\hline 40.00 & $16.82 \pm 5.06^{\mathrm{a}}$ & -12.08 & $52.25 \pm 12.87^{\mathrm{b}}$ & +22.22 & $5.40 \pm 1.66^{\mathrm{a}}$ & -2.72 & $8.30 \pm 1.04^{\mathrm{b}}$ & -76.12 & $9.82 \pm 6.32^{\mathrm{a}}$ & +7.91 \\
\hline 50.00 & $16.30 \pm 5.50^{\mathrm{a}}$ & -14.79 & $54.75 \pm 11.90^{\mathrm{b}}$ & +28.07 & $8.30 \pm 3.87^{\mathrm{b}}$ & +50.36 & $2.75 \pm 1.10^{\mathrm{a}}$ & -92.09 & $19.12 \pm 2.46^{\mathrm{b}}$ & +110.11 \\
\hline
\end{tabular}

Means within the same row with different superscripts ${ }^{(a, b, a b, c)}$ differ significantly $(\mathrm{p}<0.05)$

Table 4: Selected metabolites in the plasma of C. gariepinusa adults exposed to detergent for 30 days (Mean $\pm \mathrm{SD})$

\begin{tabular}{|c|c|c|c|c|c|c|c|c|c|c|}
\hline $\begin{array}{l}\text { Conc. } \\
\left(\mathrm{mg} \mathrm{L}^{-1}\right)\end{array}$ & $\begin{array}{l}\text { Albumin } \\
\left(\mathrm{mg} \mathrm{L}^{-1}\right)\end{array}$ & $\begin{array}{l}\text { Control } \\
(\%)\end{array}$ & $\begin{array}{l}\text { Total protein } \\
\left(\mathrm{mg} \mathrm{L}^{-1}\right)\end{array}$ & $\begin{array}{l}\text { Control } \\
(\%)\end{array}$ & $\begin{array}{l}\text { Creatinin } \\
\left(\mathrm{mg} \mathrm{L}^{-1}\right)\end{array}$ & $\begin{array}{l}\text { Control } \\
(\%)\end{array}$ & $\begin{array}{l}\text { Total bilirubin } \\
\left(\mathrm{mg} \mathrm{L}^{-1}\right)\end{array}$ & $\begin{array}{l}\text { Control } \\
(\%)\end{array}$ & $\begin{array}{l}\text { Urea } \\
\left(\mathrm{mg} \mathrm{L}^{-1}\right)\end{array}$ & $\begin{array}{l}\text { Control } \\
(\%)\end{array}$ \\
\hline 0.00 & $21.00 \pm 2.07^{\mathrm{a}}$ & 100 & $50.00 \pm 2.47^{\mathrm{a}}$ & 100 & $1.10 \pm 0.47^{\mathrm{a}}$ & 100 & $9.63 \pm 2.41^{\mathrm{a}}$ & 100 & $7.00 \pm 1.47^{\mathrm{a}}$ & 100 \\
\hline 10.00 & $26.00 \pm 1.47^{\mathrm{ab}}$ & +23.81 & $50.00 \pm 2.20^{\mathrm{a}}$ & 0.00 & $1.90 \pm 2.17^{\mathrm{a}}$ & +72.73 & $11.13 \pm 1.17^{\mathrm{ab}}$ & +15 & $6.50 \pm 2.01^{\mathrm{a}}$ & -7.14 \\
\hline 20.00 & $31.00 \pm 2.42^{\mathrm{ab}}$ & +47.62 & $50.00 \pm 1.37^{\mathrm{a}}$ & 0.00 & $1.90 \pm 1.27^{\mathrm{a}}$ & +72.73 & $12.80 \pm 2.07^{\mathrm{ab}}$ & +32.92 . & $11.00 \pm 0.47^{\mathrm{ab}}$ & +57.14 \\
\hline 30.00 & $38.00 \pm 2.07^{\mathrm{ab}}$ & +80.95 & $50.00 \pm 2.07^{\mathrm{a}}$ & 0.00 & $2.83 \pm 2.11^{\mathrm{ab}}$ & +157.27 & $15.70 \pm 1.47^{\mathrm{b}}$ & +63.03 & $13.00 \pm 1.42^{\mathrm{b}}$ & +85.71 \\
\hline 40.00 & $39.00 \pm 2.17^{\mathrm{ab}}$ & +85.71 & $50.00 \pm 2.43^{\mathrm{a}}$ & 0.00 & $3.73 \pm 2.00^{\mathrm{b}}$ & +239.09 & $20.70 \pm 2.00^{c}$ & +114.95 & $13.25 \pm 2.23^{b}$ & +87.29 \\
\hline 50.00 & $44.00 \pm 2.47^{\mathrm{b}}$ & +109.52 & $50.00 \pm 2.47^{a}$ & 0.00 & $4.18 \pm 2.47^{\mathrm{b}}$ & +280.00 & $22.75 \pm 2.47^{\mathrm{c}}$ & +136.24 & $13.33 \pm 2.47^{\mathrm{b}}$ & +90.43 \\
\hline
\end{tabular}

Means within the same column with different superscripts ${ }^{(\mathrm{a}, \mathrm{b}, \mathrm{ab}, \mathrm{c})}$ differ significantly $(\mathrm{p}<0.05)$

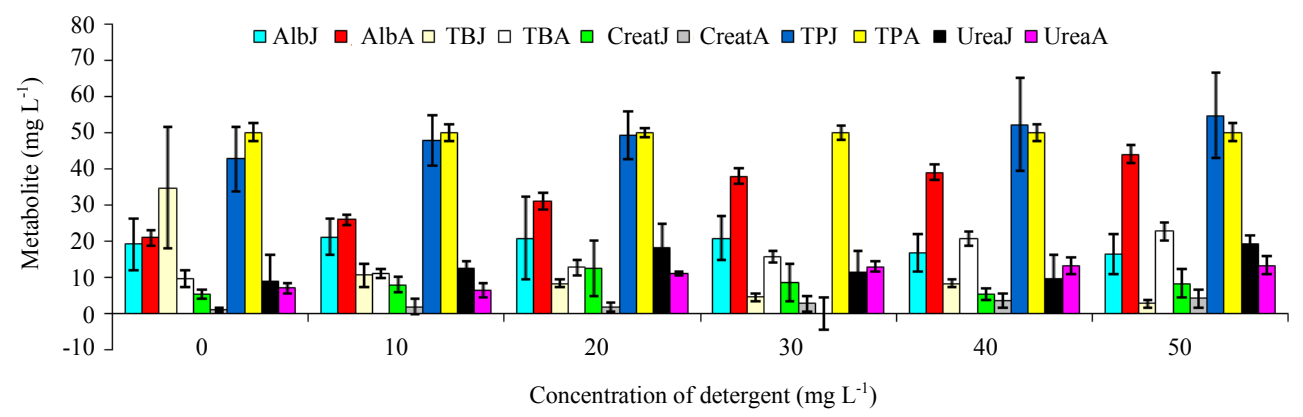

Fig. 2: Comparative levels of metabolites in the plasma of juvenile and adult $C$. gariepinus exposed to jumbo detergent for 30 days $(\mathrm{Mean} \pm \mathrm{SD})$. AlbJ =Albumin in Juvenile; AlbA=Albumin in Adult; TBJ = Total Bilirubin in Juvenile; $\mathrm{TBA}=$ Total Bilirubin in Adult; Creat $\mathrm{J}=$ Creatinine in Juvenile; Creat $\mathrm{A}=$ Creatinine in Adult; TPJ $=$ Total protein in Juvenile; TPA = Total Protein in Adult; UreaJ = Urea in Juvenile; UreaA = Urea in Adult

$30.00 \mathrm{mg} \mathrm{L}^{-1}, 76.12 \%$ at $40.00 \mathrm{mg} \mathrm{L}^{-1}$ and $92.09 \%$ at $50.00 \mathrm{mg} \mathrm{L}^{-1}$ while in adult fish it was raised by $15.58 \%$ at $10.00 \mathrm{mg} \mathrm{L}^{-1}, 32.92 \%$ at $20.00 \mathrm{mg} \mathrm{L}^{-1}, 63.03 \%$ at $30.00 \mathrm{mg} \mathrm{L}^{-1}, 114.95 \%$ at $40.00 \mathrm{mg} \mathrm{L}^{-1}$ and $136.24 \%$ at $50.00 \mathrm{mg} \mathrm{L}^{-1}$ when compared with control. At $10.00 \mathrm{mg} \mathrm{L}^{-1}$ urea in juvenile fish was $36.67 \%$ higher than control while that of adult was $7.14 \%$ less than control (Fig. 2). It was observed that urea in adult fish at $40.00 \mathrm{mg} \mathrm{L}^{-1}$ was $79.38 \%$ higher than that of juvenile fish but at 20.00, 30.00 and $50.00 \mathrm{mg} \mathrm{L}^{-1}$, it was respectively higher in juvenile fish by $41.43,17.59$ and $19.68 \%$ when compared with control (Table 3 and 4).

Detergents have been found to induce poisonous effects and osmoregulatory imbalances in aquatic lives, especially, if present in concentration that exceed metabolic demand. This xenobiotic compound could be persistent and more mobile in soil and water; hence, it is known to be one of the most common terrestrial and aquatic contaminants. In solution, detergent induce severe damage to vital organs like the gill, liver, kidney, muscle, plasma, heart and brain.
This research showed a number of deviations from the control which is the primary base for comparison in this research. However, it was observed that most of the values obtained in the physicochemical parameters in both live stages fell within Federal Environment protection Agency ${ }^{[1]}$ specifications but that is not to say that, their residual effects which impairs organs like gill, liver, kidney, muscle, plasma, heart and brain and genital organ should be ruled out. High ammonia, alkalinity, $\mathrm{pH}$, conductivity, turbidity in detergent solution with juvenile fish except in Dissolved Oxygen (DO) and low ammonia, $\mathrm{pH}$ and Dissolved Oxygen (DO) except for alkalinity, conductivity and turbidity in detergent solution with adult fish could be attributed to the impact of detergent. Adewoye and Fawole ${ }^{[12]}$ and Adewoye et al.$^{[13]}$ earlier reported that indiscriminate dumping of effluents into an aquatic system decreases the dissolved oxygen concentration which stand to impair respiration and other vital organs of the body. The inability of the kidney to retain large molecular weight proteins which were lost via. urine affected values in the serum total protein and 
albumin of the two live stages of fish. Urea and creatinin have been used as important indices for the evaluation of the effects of chemicals on kidney, muscle, gill, liver and plasma $^{[14]}$. Creatinin and urea in the gill, kidney, muscle and serum plasma fluctuated in activities as concentration increased except in the liver where activities increased as detergent concentration increased. This is in agreement with John ${ }^{[15]}$ who opined that the influence of toxicants on an organ is a function of its strength. It could be said that the irregular response of urea and creatine to detergent as concentration increased may imply that the glomerular filtration rate of the kidney had a slight stress. In the present study a significant increase in the total bilurubin content was noted with all the concentrations in all the organs of the adult fish when compared to juveniles where reductions were recorded. Similar results were observed in T. mossambicatreated with phosphamidon ${ }^{[16]}$ and in C. gariepinus exposed to potassium permanganat $\mathrm{e}^{[17]}$. The disparity in the level of bilurubin between adult and juvenile fish may be due to the immaturity of the organs in handling the increased quantity of the toxicants ${ }^{[18]}$. Ekam and and Udosen ${ }^{[19]}$ reported that the effect of activity directed fractions of Vernonia amygdalina on serum total protein, albumin and globulin levels examined in his study. It was observed that the result obtained significantly decreased $(p<0.05)$ in total protein and globulin levels in the xenobiotic group compared to that of the normal control group. This is not in agreement with this research in that the increase in detergent concentration raised total protein in adult fish when compared with control.

his increase in total protein with increase in detergent concentration also disagrees with the findings of George who posited that the decrease in serum protein in hepatotoxicity states simply indicates the presence of para proteins or decreased antibody production. It was also observed by Ekam and and Udosen ${ }^{[19]}$ that a significant increase $(\mathrm{p}<0.05)$ in total protein levels in groups treated with the various fractions of Vernonia amygdalina with residue $\mathrm{E}$ having the highest protein levels compared to xenobiotic group. There was also an insignificant decrease $(\mathrm{p}>0.05)$ in albumin levels in the remaining groups treated with the various fractions of Vernonia amygdalina. This is not in total agreement with this research in that at $10.00,20.00$ and $30.00 \mathrm{mg} \mathrm{L}^{-1}$, albumin level was higher than control in adult fish but less than control at 40.00 and $50.00 \mathrm{mg} \mathrm{L}^{-1}$. The result of the present study strongly suggests that at various concentration levels the impact of detergent on the metabolites of the two life stages of fish is relative in terms of age in that it caused the decrease in total bilirubin in juvenile fish and raised that of creatinine, urea and total bilirubin of the two life stages.

\section{CONCLUSION}

This study assessed the chronic effect of linear alkyl benzene sulphonateon the metabolites in the blood plasma of Clarias gariepinus juveniles and adults, a common Niger delta wetland fish. Significance variations in the metabolites (albumin, total protein, creatinine, total bilirubin and urea) content of two life stages of Clarias gariepinus exposed to detergent were carefully monitored in comparison with control. This research confirms that metabolites is a potential bio marker in monitoring chronic toxicity of linear alkyl benzene sulphonate in fisheries. Relevant agencies must let the public know the inherent danger that the indiscriminate use of detergent could pose to aquatic lives, especially when copiously used close to in-land water and or fish ponds.

\section{REFERENCES}

01. Hinton, D.E. and D.J. Lauren, 1990. Integrative Histopathological Approaches to Detecting Effects of Environmental Stressors on Fishes. In: Biological Indicators of Stress in Fish, Adams, S.M. (Ed.). Bethesda Publisher, Maryland, pp: 51-66.

02. Sembulingam, K. and P. Sembulingam, 2013. Essentials of Medical Physiology. 6th Edn., Jaypee Publication, Tamil Nadu, India, ISBN: 978-93-5025-936-8, Pages: 1113.

03. Chavin, W., 2003. Ultrastructure of mucous cells in the integument of fish. J. Electron Microsc., 2: 409-422.

04. Segner, H. and T. Braunbeck, 1988. Hepatocellular adaptation to extreme nutritional conditions in ide, Leuciscus idus melanotus L. (Cyprinidae). A morphofunctional analysis. Fish Physiol. Biochem., 5: 79-97.

05. Trump, B.F., E.M. Mcdowell and A.U. Arstila, 1980. Cellular Reaction to Injury. In: Principles of Pathology, Hill, R.B. and M.F. LaVia (Eds.). 3rd Edn. Oxford University Press, New York, USA., pp: 20-111.

06. Gagnon, L., C. Jumarie and A. Hontela, 2006. Effect of Industrial effluent on plasma cortisol and cortisol secretion by adrenocurtical cells of rainbow trout Oncorhynchus mykiss. Aquat. Toxicol., 78: 59-65.

07. Bielinska, I., 1987. Dielectric, haematological and biochemical studies of detergent toxicity in fish blood. Phys. Med. Biol., 32: 623-635.

08. Panasenko, O.M., S.A. Evgina, E.S. Driomina, V.S. Sharov, V.I. Sergienko and Y.A. Vladimirov, 1995. Hypochlorite induces lipid peroxidation in blood lipoproteins and phospholipid liposomes. Free Radical Biol. Med., 19: 133-140. 
09. Omotoso, F.O. and O.A. Fagbero, 2005. A comparative study on the toxicity of three commercial detergents on the survival of the Nile Tilapia, Oreochromis niloticus. J. Agric. Resour. Dev., 4: 139-147.

10. Begum, G., 2005. In vivo biochemical changes in liver and gill of Clarias batrachus during cypermethrin exposure and following cessation of exposure. Pestic. Biochem. Physiol., 82: 185-196.

11. FEPA., 1991. Guideline and Standard for Environmental Pollution Control in Nigeria. Federal Environmental Protection Agency (FEPA), Nigeria, Pages: 238.

12. Adewoye, S.O. and O.O. Fawole, 2002. Acute toxicity of soap and detergent effluent to fresh water Clarias gariepinus fingerlings. Afr. J. Sci., 22: 112-118.

13. Adewoye, S.O., O.O. Fawole, O.D. Owolabi and J.S. Omotosho, 2005. Toxicity of cassava wastewater effluents to African catfish: Clarias gariepinus (Burchell, 1822). Ethiopia J. Sci., 28: 189-194.

14. Kime, D.E., 2008. Endocrime Disruption in Fish. Kluwes Academic Publishers Norwell, Massachusett, USA.,.
15. John, P.J., 2007. Alteration of certain blood parameters of freshwater teleost Mystus vittatus after chronic exposure to Metasystox and Sevin. Fish Physiol. Biochem., 33: 15-20.

16. James, R., K. Sampath and S. Alagurathinam, 1996. Effects of lead on respiratory enzyme activity, glycogen and blood sugar levels of the teleost Oreochromis mossambicus (Peters) during accumulation and depuration. Asian Fish. Sci., 9: 87-100.

17. Ovie, K.S., 2008. Effects of sublethal concentrations of potassium permanganate on nitrogenous waste products of African catfish: Clarias gariepinus (Burchell, 1822). Int. J. Integr. Biol., 4: 40-44.

18. Abedi, Z., M.K. Khalesi, E.S. Kohestan and H. Rahmani, 2012. Comparison of lethal concentrations (LC50-96 h) of $\mathrm{CdCl} 2, \mathrm{CrCl} 3$ and $\mathrm{Pb}$ (NO3)2 in Common Carp (Cyprinus carpio) and Sutchi Catfish (Pangasius hypophthalmus). Iran. J. Toxicol., 6: 672-680.

19. Ekam, V.S. and E.O. Udosen, 2012. Total protein, albumin and globulin levels following the administration of activity directed fractions of Vernonia amygdalina during acetaminophen induced hepatotoxicity in Wistar albino rats. Global J. Pure Applied Sci., 18: 25-29. 